\title{
CCR2 and CCR5 genes polymorphisms in women with cervical lesions from Pernambuco, Northeast Region of Brazil: a case-control study
}

\author{
Erinaldo Ubirajara Damasceno dos Santos', Géssica Dayane Cordeiro de Lima², \\ Micheline de Lucena Oliveira ${ }^{3}$, Sandra de Andrade Heráclio ${ }^{4}$, Hildson Dornelas Angelo da Silva ${ }^{5,6}$, \\ Sergio Crovella ${ }^{6}$, Maria de Mascena Diniz Maia ${ }^{1}$, Paulo Roberto Eleutério de Souza ${ }^{1,2}{ }^{+}$
}

\author{
${ }^{1}$ Universidade Federal Rural de Pernambuco, Programa de Pós-Graduação em Ciência Animal Tropical, Recife, PE, Brasil \\ ${ }^{2}$ Universidade de Pernambuco, Programa de Pós-Graduação em Biologia Celular e Molecular Aplicada, Recife, PE, Brasil \\ ${ }^{3}$ Laboratório Central de Saúde Pública de Pernambuco, Recife, PE, Brasil ${ }^{4}$ Instituto de Medicina Integral Prof. Fernando Figueira, \\ Recife, PE, Brasil ${ }^{5}$ Instituto Federal de Pernambuco, Garanhuns, PE, Brasil ${ }^{6}$ Universidade Federal de Pernambuco, \\ Programa de Pós-Graduação em Genética, Recife, PE, Brasil
}

Polymorphisms in chemokine receptors play an important role in the progression of cervical intraepithelial neoplasia (CIN) to cervical cancer (CC). Our study examined the association of CCR2-64I (rs1799864) and CCR5- $\Delta 32$ (rs333) polymorphisms with susceptibility to develop cervical lesion (CIN and CC) in a Brazilian population. The genotyping of 139 women with cervical lesions and 151 women without cervical lesions for the CCR2-64I and CCR5- $\Delta 32$ polymorphisms were performed using polymerase chain reaction-restriction fragment length polymorphism. The individuals carrying heterozygous or homozygous genotypes (GA+AA) for CCR2-64I polymorphisms seem to be at lower risk for cervical lesion [odds ratio $(O R)=0.37, p=0.0008)]$. The same was observed for the A allele $(O R=0.39, p=0.0002)$, while no association was detected ( $p>0.05$ ) with CCR5- $\Delta 32$ polymorphism. Regarding the human papillomavirus $(H P V)$ type, patients carrying the CCR2-64I polymorphism were protected against infection by HPV type 16 (OR = $0.35, p=0.0184$ ). In summary, our study showed a protective effect of CCR2-64I rs1799864 polymorphism against the development of cervical lesions (CIN and CC) and in the susceptibility of HPV 16 infection.

Key words: chemokine receptors - cervical intraepithelial neoplasia - cervical cancer - single nucleotide polymorphism

Infections by oncogenic types of human papillomavirus (HPV) are found in $99 \%$ of women with cervical cancer (CC) (de Oliveira et al. 2013). Therefore, this virus is classified as the most important carcinogenic risk factor according to the criteria of the International Agency for Research on Cancer (Bonanni et al. 2015). Among more than 120 types of HPV have been identified, 18 of these are classified as high-risk oncogenic (Bouvard et al. 2009, Bernard et al. 2010). However, the majority of women infected with HPV will not develop cervical carcinoma, since the carcinogenic process depends on several other genetic, environmental, and immune factors (Zheng et al. 2006).

The loss of cell cycle control mechanism, infiltration of leukocyte, and of other immunocompetent cells, as well as the altered expression of immune response genes, have been considered critical in neoplasms cervical pathogenesis and progression for CC (Evans et al. 1997, Ghaderi et al. 2000, O’Brien et al. 2001).

Among the gene products present into cervical mucosa, chemokines and their receptor have shown a key role in immunity against cervical tumours (Ghaderi et

doi: 10.1590/0074-02760150367

Financial support: FACEPE, CNPq

+ Corresponding author: prsouza30@gmail.com

Received 25 September 2015

Accepted 29 January 2016 al. 2000, Ohta et al. 2002). Chemokines are chemoattractant proteins of low molecular weight that promote adhesiveness of target cells; then the angiogenesis process drive homing of phagocytes and lymphocytes into secondary lymphoid organs (Rossi \& Zlotnik 2000, Kleine-Lowinski et al. 2003, Zheng et al. 2006). The receptors for chemokines are mainly expressed on immune cells and assist in the differentiation and migration of these cells to inflamed tissues (Bromley et al. 2005).

Chemokine receptor $(\mathrm{CCR}) 5$ is the major receptor for the chemokine and their ligands are the macrophage inflammatory protein (MIP)-1 $\alpha /$ chemokine ligand (CCL)3, MIP-1 $\beta / C C L 4$, and regulated on activation, normal $\mathrm{T}$ cell expressed and secreted/CCL5 (Lehner 2002, Al-Abdulhadi \& Al-Rabia 2010, Ahmadabadi et al. 2012). Polymorphic variations in this gene, in particular the $\Delta 32$ mutation (a 32 bp deletion in the CCR5 gene) leads to decreased expression and dysfunction of CCR5 receptor (Nahon et al. 2008, Ahmadabadi et al. 2012). Studies report that individuals homozygotes for CCR5- $\triangle 32$ (rs333) gene have reduced risk for asthma and early-onset myocardial infarction, attenuation of severity in rheumatoid arthritis, and slower acquired immune deficiency syndrome (AIDS) progression (Berger et al. 1999, Hall et al. 1999, Zapico et al. 2000, González et al. 2001). In addition CCR5, together with CCR2, act as co-receptors for human immunodeficiency virus-1 (Zheng et al. 2006).

CCR 2 is the receptor for CCL 2, also known as monocyte chemoattractant protein (MCP)-1, being associated with carcinogenesis and angiogenesis (Charo et al. 1994, Zhang et al. 2003, Koide et al. 2004, Huang 
et al. 2013). The single nucleotide polymorphism at codon 64 (CCR2-64I, rs1799864) of CCR2 gene that encodes isoleucine (ATC) instead of valine (GTC) has been widely studied, and there are reports of association between this polymorphism and the protective effect in the progression of inflammatory diseases such as multiple sclerosis (Miyagishi et al. 2003), carotid atherosclerosis (Nyquist et al. 2009), and in development of breast cancer (Zafiropoulos et al. 2004). However, conflicting results on the role of the $C C R 5$ and $C C R 2$ polymorphisms in the development of the CC have been reported so far (Coelho et al. 2005, Zheng et al. 2006, Ivansson et al. 2007, Chatterjee et al. 2010).

Therefore, the aim of this study was to analyse the association for CCR2-64I and CCR5- 432 polymorphisms with development of cervical intraepithelial neoplasia (CIN) or CC in women infected by HPV from Northeast Region of Brazil.

\section{SUBJECTS, MATERIALS AND METHODS}

Population - The present study was a hospital-based cross-sectional prospective one carried out in the outpatient clinics of the Lower Genital Tract Pathology Clinic at the Women's Healthcare Center of the Prof Fernando Figueira Institute of Integrated Medicine, Recife, state of Pernambuco, Brazil. Patients were selected by spontaneous demand from January 2009 until 2011 and the study population consisted of 290 sexually active women ranging between 16-75 years old. Information was collected from all women pertaining to their age, smoking, alcohol consumption, number of offspring, number of sexual partners, and age at first coitus. The inclusion criteria was as follows: women with oncotic cytology submitted to Papanicolaou test (cytological) according to Bethesda System terminology (Solomon et al. 2002) performed on the state accredited networks, presenting diagnostic of $\mathrm{CIN}$ of low-grade and high-grade or $\mathrm{CC}$, and confirmed by histological analysis. Subjects were evaluated for clinical features of other sexually transmitted infections on history and examination. Patients that were previously submitted to radiotherapy or chemotherapy to invasive CC were excluded. The Institutional Ethical Committee approved this study (protocol 355/08). Informed written consent was taken from the women informing them about the background of the study, risks and benefits, and voluntary nature of participation. After histological analysis, patients were stratified according to the presence or absence of cervical lesion (CIN or CC) as case and control groups, respectively.

Clinical samples - Cervical smears were obtained using Cytobrushes. Each Cytobrush was packed in a Trisethylenediamine tetraacetic acid (EDTA) buffer solution (Tris- $\mathrm{HCl} 10 \mathrm{mM}$ and EDTA $1 \mathrm{mM} \mathrm{pH} \mathrm{8.0)} \mathrm{and} \mathrm{con-}$ served at $-20^{\circ} \mathrm{C}$ until analysis.

DNA extraction - Genomic DNA extraction was performed from $300 \mu \mathrm{L}$ of vaginal fluid from each study subject, following the manufacturer's instructions of the kit Wizard ${ }^{\circledR}$ Genomic DNA Purification (Promega, USA). The analyses samples were executed the Laboratory of Genetics, Biochemistry, and DNA Sequencing at Rural Federal University of Pernambuco.
$H P V$ detection and typing - Amplification of human $\beta$-globin gene segment was used as an internal control for DNA quality and samples negative for this assay were excluded from analysis. Then, our samples were tested for HPV presence using MY09/11, GP05+ and GP06+ consensus primers by polymerase chain reaction (PCR) (Tavares et al. 2014). The typing of high-risk HPV (HR-HPV) 16, 18, 31, and 33 was performed using specific primers (da Silva et al. 2009, Tavares et al. 2015).

Analysis of the CCR2-64I polymorphism - The CCR2-64I polymorphism was analysed through PCR followed by restriction fragment length polymorphism (Coelho et al. 2005). DNA was amplified using primers sense 5'-TTGTGGGCAACATGATGG-3' and antisense 5'-GCATTCCCAAAGACCCACTC-3'. The PCR products of $163 \mathrm{bp}$ length were then digested with $B s a B I$ restriction enzyme. The fragments originated after of the use the restriction enzyme, 163 bp for $\mathrm{G}$ allele, and 145 and $18 \mathrm{bp}$ for $\mathrm{A}$ allele were revealed using 3\% agarose gel stained with gel red (UNISCIENCE).

Analysis of the CCR5-432 polymorphism - The CCR5- 432 polymorphism was analysed through PCR (Kristiansen et al. 2001) using primers sense 5'-CTTCATCATCCTC-CTGACAATCG-3' and antisense 5'-GACCAGCCCCAAGTTGACTATC-3'. PCR products of $262 \mathrm{bp}$ for CCR 5 wild-type allele and $230 \mathrm{bp}$ for CCR5- $\triangle 32$ allele were detected with 3\% agarose gel stained with gel red (UNISCIENCE).

Sequencing - A total of $20 \%$ of the all samples (randomly chosen) was submitted to bidirectional sequencing (MegaBACE 1000 DNA sequencer; GE Healthcare, USA) in order to double-check the genotyping results for each polymorphism (Tavares et al. 2015).

Statistical analyses - Univariate statistical analysis was performed using the BioEstat 5.0 software. The study was cross-sectional with independent samples consisting of nominal data (genotypes). The influence of each polymorphism on the risk for development of (pre) neoplastic cervical disease was estimated by odds ratio (OR) and a 95\% confidence interval (CI). Allele frequencies were estimated by direct counting. Comparison between genotypic frequencies of patients and control groups was performed by chi-square test and Fisher's exact test was used to compare the allele frequencies in contingency tables.

For identification of relevant risk factors, a logistic regression analysis was carried out (comparing HPVpositive women with history of lesions with HPV-positive women with no history of lesions or CC). This modelled the influence of genetic polymorphisms, HPV 16 single infection or multiple HPV strains co-infection, smoking and alcohol consumption on the risk of developing highgrade squamous intraepithelial lesions. The OR and their respective $95 \% \mathrm{CI}$ were determined. The $\mathrm{R}$ software v.3.0.2 (R-project.org/) was used to perform the regression analysis. Power analysis was performed through G*Power software v.3.1.9.2 (Faul et al. 2007). All p-values $\leq 0.05$ were considered statistically significant. 


\section{RESULTS}

Within the $290 \mathrm{HPV}$ positive enrolled women, 139 had cervical lesions (CIN or CC) $(\mathrm{HPV}+\mathrm{L})$ while the 151 had no cervical lesions $(\mathrm{HPV}+)$. When considering the prevalence of type-specific HR-HPV infection, we ob- served that $38.8 \%$ of the patients had HPV $16,22.3 \% \mathrm{HPV}$ 18, 2.9\% HPV 31, 3.6\% HPV 33, and 14.4\% other HPV types. Furthermore, the presence of co-infection by HPV types $16 / 18$ was found in $18 \%$ of the patients (Table I). Moreover, when the patients were stratified according to

TABLE I

Human papillomavirus (HPV) genotypes prevalence and histologic diagnosis

\begin{tabular}{lcccc}
\hline & CIN I & CIN II/III \\
Types & $\begin{array}{c}\mathrm{n}=40) \\
\mathrm{n}(\%)\end{array}$ & $\begin{array}{c}\text { CC } \\
\mathrm{n}(\%)\end{array}$ & $\begin{array}{c}\text { Total } \\
(\mathrm{n}=12) \\
\mathrm{n}(\%)\end{array}$ & $\begin{array}{c}\mathrm{n}=139) \\
\mathrm{n}(\%)\end{array}$ \\
\hline HPV 16 & $10(25)$ & $38(43.7)$ & $6(50)$ & $54(38.8)$ \\
HPV 18 & $9(22.5)$ & $20(22.9)$ & $2(16.7)$ & $31(22.3)$ \\
HPV 31 & $2(5)$ & $2(2.3)$ & $0(0)$ & $4(2.9)$ \\
HPV 33 & $0(0)$ & $4(4.6)$ & $1(8.3)$ & $5(3.6)$ \\
Others HPV & $14(35)$ & $5(5.8)$ & $1(8.3)$ & $20(14.4)$ \\
Co-infection (16/18) & $5(12.5)$ & $18(20.7)$ & $2(16.7)$ & $25(18)$ \\
\hline
\end{tabular}

CC: cervical cancer; CIN: cervical intraepithelial neoplasia.

\section{TABLE II}

Genotypic distribution of the CCR2-64I and CCR5- $\triangle 32$ gene polymorphisms in human papillomavirus (HPV) positive patients with cervical intraepithelial neoplasia (CIN) and cervical cancer $(\mathrm{CC})(\mathrm{HPV}+\mathrm{L})$ or without cervical lesions $(\mathrm{HPV}+)$

\begin{tabular}{|c|c|c|c|c|c|}
\hline SNP & $\begin{array}{c}\text { HPV+ } \\
(\mathrm{n}=151) \\
\mathrm{n}(\%)\end{array}$ & $\begin{array}{c}\mathrm{HPV}+\mathrm{L} \\
(\mathrm{n}=139) \\
\mathrm{n}(\%)\end{array}$ & $\begin{array}{l}\chi^{2} \\
(p)\end{array}$ & $\begin{array}{c}\text { OR } \\
(95 \% \mathrm{CI})\end{array}$ & $\mathrm{p}^{a}$ \\
\hline \multicolumn{6}{|l|}{ CCR2 64I genotypes } \\
\hline GG & $99(65.6)$ & $116(83.4)$ & & 1 & \\
\hline GA & $43(28.4)$ & $21(15.1)$ & $\begin{array}{c}8.820 \\
(0.0047)\end{array}$ & $\begin{array}{c}0.42 \\
(0.23-0.75)\end{array}$ & 0.0047 \\
\hline AA & $9(6)$ & $2(1.5)$ & $\begin{array}{c}5.367 \\
(0.0447)\end{array}$ & $\begin{array}{c}0.19 \\
(0.04-0.89)\end{array}$ & 0.0447 \\
\hline $\mathrm{AA}+\mathrm{GA} \times \mathrm{GG}$ & $52 / 99(52.5)$ & 23/116 (19.8) & $\begin{array}{c}12.082 \\
(0.0005)\end{array}$ & $\begin{array}{c}0.37 \\
(0.21-0.66)\end{array}$ & 0.0008 \\
\hline \multicolumn{6}{|l|}{ Allele } \\
\hline G & $241(79.8)$ & $253(91)$ & $\begin{array}{c}14.393 \\
(0.0001)\end{array}$ & 1 & \\
\hline A & $61(20.2)$ & $25(9)$ & & $\begin{array}{c}0.39 \\
(0.23-0.64)\end{array}$ & 0.0002 \\
\hline \multicolumn{6}{|l|}{$C C R 5-\triangle 32$ genotypes } \\
\hline WT/WT & $141(93.3)$ & $125(89.9)$ & & 1 & \\
\hline $\mathrm{WT} / \Delta 32$ & $10(6.7)$ & $14(10.1)$ & $\begin{array}{c}1.134 \\
(0.2868)\end{array}$ & $\begin{array}{c}1.57 \\
(0.67-3.68)\end{array}$ & 0.3943 \\
\hline$\Delta 32 / \Delta 32$ & $0(0)$ & $0(0)$ & ND & ND & ND \\
\hline $\mathrm{WT} / \Delta 32+\Delta 32 / \Delta 32 \times \mathrm{WT} / \mathrm{WT}$ & $10 / 141(7)$ & $14 / 125(11.2)$ & $\begin{array}{c}1.134 \\
(0.2868)\end{array}$ & $\begin{array}{c}1.57 \\
(0.67-3.68)\end{array}$ & 0.3943 \\
\hline \multicolumn{6}{|l|}{ Allele } \\
\hline WT & $292(96.7)$ & 264 (94.9) & & 1 & \\
\hline$\Delta 32$ & $10(3.3)$ & $14(5.1)$ & $\begin{array}{c}1.085 \\
(0.2975)\end{array}$ & $\begin{array}{c}1.54 \\
(0.67-3.54)\end{array}$ & 0.4047 \\
\hline
\end{tabular}

$a$ : value of the odds ratio (OR); CI: confidence interval; ND: not determined; SNP: single nucleotide polymorphism; WT: wildtype; $\chi^{2}$ : chi-square test. Bolded values mean significant values. 
the severity of cervical lesions, $28.78 \%$ (40/139) exhibited CIN I (low-degree of lesion), 62.58\% (87/139) had CIN II or III (high-degree of lesion), and 8.63\% (12/139) had CC.

Among the $139 \mathrm{HPV}+\mathrm{L}$, five risk factors for cervical lesions were analysed: smoking, alcohol consumption, number of offspring, number of sexual partners, and age at first coitus. With the $139 \mathrm{HPV}+\mathrm{L}, 32.37 \%(45 / 139)$ reported smoking, 60.03\% (89/139) alcohol consumption, $28.78 \%$ (40/139) number of offspring $>3,20.17 \%$ $(24 / 119)$ had number of sexual partners $>4$, and $59.71 \%$ $(83 / 139)$ had first coitus with $\leq 16$ years old.

The distribution of CCR2-64I and CCR5- $\triangle 32$ polymorphisms genotypes in 139 women with cervical lesions (CIN or CC) and $151 \mathrm{HPV}+$ were according to the Hardy-Weinberg equilibrium. A significant difference in the distribution of CCR2-64I polymorphism between $\mathrm{HPV}+\mathrm{L}$ and $\mathrm{HPV}+$ was observed using a dominant genetic model $(\mathrm{OR}=0.37 ; \mathrm{p}=0.0005)$, being the variant carrier (GA+AA) associated with protection to cervical lesions (Table II). When considering the CCR5-432 polymorphism, no statistical difference between HPV+$\mathrm{L}$ and HPV+ was observed $(\mathrm{p}=0.3943)$ (Table II).

Statistical significant association was found between CCR2-64I polymorphism and susceptibility to
HPV 16 infection $(\mathrm{OR}=0.35 ; \mathrm{p}=0.0184)$ (Table III); the CCR5- 432 variant did not show any association with HPV types studied.

Patients clinical features are shown in Table IV. There were no significant statistical differences between CCR2$64 I$ and CCR5- 432 polymorphisms with age, smoking, alcohol consumption, number of offspring, number of sexual partners, or age at first coitus ( $\mathrm{p}>0.05)$.

\section{DISCUSSION}

In this study, we examined the possible association between CCR2-64I and CCR5- $\triangle 32$ polymorphisms and the presence of cervical lesions (CIN or CC) in HPV infected women from Northeast Region of Brazil.

The CCRs genes CCR5 and CCR2 have been associated with carcinogenesis and angiogenesis (Zheng et al. 2006), inflammatory disorders, and autoimmune diseases (Rossi \& Zlotnik 2000). Immunological studies, regarding to immune response genes, showed a significant decrease in intraepithelial macrophages (Tay et al. 1987), Langerhans cells (Spinillo et al. 1993), and cytotoxic T lymphocytes in CIN advanced (Evans et al. 1997).

The CCR2-64I polymorphism has been reported to influence several diseases as multiple sclerosis (Miyag-

TABLE III

Genotypic distribution of the CCR2-64I and CCR5- 432 polymorphisms in human papillomavirus (HPV)-16 positive patients and in patients with HPV genotypes other than type 16

\begin{tabular}{|c|c|c|c|c|c|}
\hline SNP & $\begin{array}{l}\text { Other HPV } \\
(\mathrm{n}=85) \\
\mathrm{n}(\%)\end{array}$ & $\begin{array}{c}\text { HPV } 16 \\
(\mathrm{n}=54) \\
\mathrm{n}(\%)\end{array}$ & $\begin{array}{l}\chi^{2} \\
(\mathrm{p})\end{array}$ & $\begin{array}{c}\text { OR } \\
(95 \% \mathrm{CI})\end{array}$ & $\mathrm{p}^{a}$ \\
\hline \multicolumn{6}{|l|}{ CCR2 64I genotypes } \\
\hline GG & $69(81.1)$ & $47(87.1)$ & & 1 & \\
\hline GA & $1(1.1)$ & $6(11.1)$ & $\begin{array}{c}13.76 \\
(0.001)\end{array}$ & $\begin{array}{c}8.80 \\
(1.02-75.56)\end{array}$ & 0.0509 \\
\hline AA & $15(17.8)$ & $1(1.8)$ & & $\begin{array}{c}0.09 \\
(0.01-0.77)\end{array}$ & 0.0167 \\
\hline $\mathrm{GG} / \mathrm{GA}+\mathrm{AA}$ & $69 / 16$ & $47 / 7$ & & $\begin{array}{c}0.64 \\
(0.24-1.68)\end{array}$ & 0.5015 \\
\hline \multicolumn{6}{|l|}{ Allele } \\
\hline G & $139(81.7)$ & $100(92.6)$ & 6.93 & 1 & \\
\hline A & $31(18.3)$ & $8(7.4)$ & $(0.031)$ & $\begin{array}{c}0.35 \\
(0.15-0.81)\end{array}$ & 0.0184 \\
\hline \multicolumn{6}{|l|}{ CCR 5- $\triangle 32$ genotypes } \\
\hline WT/WT & $80(94.1)$ & $46(85.2)$ & & 1 & \\
\hline $\mathrm{WT} / \Delta 32$ & $5(5.9)$ & $8(14.8)$ & $\begin{array}{c}3.01 \\
(0.221)\end{array}$ & $\begin{array}{c}2.78 \\
(0.86-9.01)\end{array}$ & 0.1432 \\
\hline$\Delta 32 / \Delta 32$ & 0 & 0 & & ND & \\
\hline $\mathrm{WT} / \mathrm{WT} \times \mathrm{WT} / \Delta 32+\Delta 32 / 32$ & $80 / 5$ & $46 / 8$ & & & \\
\hline \multicolumn{6}{|l|}{ Alelle } \\
\hline WT & $165 / 170(97.1)$ & $100 / 108(92.6)$ & & 1 & \\
\hline$\Delta 32$ & $5 / 170(2.9)$ & 8/108 (7.4) & $\begin{array}{c}2.86 \\
(0.239)\end{array}$ & $\begin{array}{c}2.64 \\
(0.84-8.29)\end{array}$ & 0.1534 \\
\hline
\end{tabular}

$a$ : value of the odds ratio (OR); CI: confidence interval; ND: not determined; SNP: single nucleotide polymorphism; WT: wildtype; $\chi^{2}$ : chi-square test. Bolded values mean significant values. 


\section{TABLE IV}

Genotypic distribution of the CCR2-64I and CCR5-432 polymorphisms in patients with cervical lesions (cervical intraepithelial neoplasia and cervical cancer and clinical features

\begin{tabular}{|c|c|c|c|c|c|c|c|}
\hline \multirow[b]{2}{*}{ Clinical features } & \multicolumn{7}{|c|}{ CCR2-64I } \\
\hline & $\mathrm{A} / \mathrm{P}$ & $(\mathrm{n}=139)$ & $\mathrm{G} / \mathrm{G}$ & $\mathrm{G} / \mathrm{A}+\mathrm{A} / \mathrm{A}$ & $\begin{array}{l}\chi^{2} \\
(p)\end{array}$ & $\begin{array}{c}\text { OR } \\
(95 \% \mathrm{CI})\end{array}$ & $\mathrm{p}^{\mathrm{a}}$ \\
\hline \multirow[t]{2}{*}{ Smoking } & $\mathrm{P}$ & 45 & 36 & 9 & \multirow[t]{2}{*}{0.4484} & 1.42 & \multirow[t]{2}{*}{0.6072} \\
\hline & $\mathrm{A}$ & 94 & 80 & 10 & & $(0.56-3.60)$ & \\
\hline \multirow[t]{2}{*}{ Alcohol consumption } & $\mathrm{P}$ & 89 & 77 & 12 & \multirow[t]{2}{*}{0.1947} & 0.55 & \multirow[t]{2}{*}{0.2896} \\
\hline & $\mathrm{A}$ & 50 & 39 & 11 & & $(0.41-4.36)$ & \\
\hline \multirow[t]{2}{*}{ Number of offspring } & $>3$ & 40 & 33 & 7 & \multirow[t]{2}{*}{0.7452} & 1.18 & \multirow[t]{2}{*}{0.9521} \\
\hline & $\leq 3$ & 79 & 67 & 12 & & $(0.42-3.28)$ & \\
\hline \multirow[t]{2}{*}{ Number of sexual partners } & $>4$ & 24 & 21 & 3 & \multirow[t]{2}{*}{$0.6038^{a}$} & 0.70 & \multirow[t]{2}{*}{$0.8360^{a}$} \\
\hline & $\leq 4$ & 95 & 79 & 16 & & $(0.18-2.65)^{a}$ & \\
\hline \multirow[t]{3}{*}{ Age at first coitus } & $\leq 16$ & 83 & 67 & 16 & \multirow[t]{2}{*}{0.2916} & 1.67 & \multirow[t]{2}{*}{0.4111} \\
\hline & $\leq 16$ & 56 & 49 & 7 & & $(0.63-4.37)$ & \\
\hline & \multicolumn{7}{|c|}{$C C R 5-\triangle 32$} \\
\hline Clinical features & $\mathrm{A} / \mathrm{P}$ & $(\mathrm{n}=139)$ & $\mathrm{Wt} / \mathrm{Wt}$ & $\mathrm{Wt} / \Delta 32+\Delta 32 / \Delta 32$ & $\begin{array}{l}\chi^{2} \\
(p)\end{array}$ & $\begin{array}{c}\text { OR } \\
(95 \% \mathrm{CI})\end{array}$ & $\mathrm{p}^{a}$ \\
\hline \multirow[t]{2}{*}{ Smoking } & $\mathrm{P}$ & 45 & 40 & 5 & \multirow[t]{2}{*}{0.6222} & 1.34 & \multirow[t]{2}{*}{0.8561} \\
\hline & $\mathrm{A}$ & 94 & 86 & 8 & & $(0.41-4.36)$ & \\
\hline \multirow[t]{2}{*}{ Alcohol consumption } & $\mathrm{P}$ & 89 & 79 & 10 & \multirow[t]{2}{*}{0.0529} & 6.20 & \multirow[t]{2}{*}{0.1077} \\
\hline & A & 50 & 49 & 1 & & $(0.77-49.96)$ & \\
\hline \multirow[t]{2}{*}{ Number of offspring } & $>3$ & 40 & 36 & 4 & \multirow[t]{2}{*}{0.9827} & 0.76 & \multirow[t]{2}{*}{0.7637} \\
\hline & $\leq 3$ & 79 & 71 & 8 & & $(0.27-3.49)$ & \\
\hline \multirow[t]{2}{*}{ Number of sexual partners } & $>4$ & 24 & 22 & 2 & \multirow[t]{2}{*}{$0.7499^{a}$} & 0.77 & \multirow[t]{2}{*}{0.9517} \\
\hline & $\leq 4$ & 95 & 85 & 10 & & $(0.15-3.78)^{a}$ & \\
\hline \multirow[t]{2}{*}{ Age at first coitus } & $\leq 16$ & 83 & 76 & 7 & \multirow[t]{2}{*}{0.6506} & 0.76 & \multirow[t]{2}{*}{0.8761} \\
\hline & $>16$ & 56 & 50 & 6 & & $(0.24-2.41)$ & \\
\hline
\end{tabular}

$a$ : were used a total of 119 patients; A: absence of the characteristic; CI: confidence interval; OR: odds ratio of A x G alleles; P: presence of the characteristic; WT: wild-type; $\chi 2$ : chi-square test.

ishi et al. 2003), carotid atherosclerosis (Nyquist et al. 2009), breast cancer (Zafiropoulos et al. 2004), AIDS progression (Smith et al. 1997, Mulherin et al. 2003), and CIN or CC (Coelho et al. 2005, Ivansson et al. 2007, Chatterjee et al. 2010). Our results showed a protective effect of CCR2-64I polymorphic variant against the development of cervical lesions $(\mathrm{OR}=0.37)$; Coelho et al. (2005) found the same outcome in a Portuguese population. Nevertheless, Chatterjee et al. (2010) and Ivansson et al. (2007) reported that the A allele conferred risk to development of CC in African and Swedish women. The contradictory results on the $\mathrm{A}$ allele in relation to the development of CIN or CC (Coelho et al. 2005, Zheng et al. 2006, Ivansson et al. 2007) might be due to its conflicting role in the macrophages recruitment reported by some authors. Wallin et al. (1999) suggested that mutant allele CCR2-64I can be linked with decreased macrophages recruitment in the process of tumour angiogenesis, which could be a key during progression of cervical ne- oplasia to CC. However, Chatterje et al. (2010) proposed that the raised attraction of the macrophages through the increased expression of MCP-1 could be auxiliary in the process of destruction or progression of tumour. These discordant findings reinforce the possibility of several factors associated with the multifactorial neoplastic development, including the difference in ethnic origin of the populations studied, sample sizes, and the low percentage of the mutant allele (CCR2-64I).

Studies reported that CCR5- $\triangle 32$ is involved in slower AIDS progression (Berger et al. 1999), in decreasing the severity of rheumatoid arthritis (Zapico et al. 2000), and in the reduced risk to asthma (Hall et al. 1999). To our knowledge until now, only one study conducted by Zheng et al. (2006) in a Swedish population related the CCR5-432 polymorphism with CC. The authors observed that individual carriers of the allele $\Delta 32$ had 4.58 fold-increased risk to HPV infection, but they did not found association in relation to progression of cervical 
lesion. In our study, we did not observe any association of $\Delta 32$ variant with development of cervical lesion ( $p>$ 0.05 ). However, to clarify the role of this genotype in both HPV infection and progression for cervical lesion, the CCR 5- $\triangle 32$ polymorphism should be tested in other populations from different ethnic background.

Regarding to prevalence of HPV infection, we found that the more frequent types were HPV 16 and 18 (38.8\% and $22.3 \%$, respectively). The prevalence of HPV 31 was $2.8 \%$ and HPV 33 was $3.5 \%$. Tavares et al. (2014) found similar results in a study conducted at Recife with 142 HPV positive women with cervical lesion. Silva et al. (2003) and Rabelo-Santos et al. (2003) observed that HPV type 16 was the most prevalent virus in all Brazilian regions, but there were variation regarding the frequencies of the type 16 in relation to other types. Furthermore, ours results are in agreement with distribution of these HPV types worldwide in women with CC ( $\mathrm{Li}$ et al. 2011). da Silva et al. (2009) evaluated the incidence of HPV types in 213 samples cervical of women in Recife, finding a higher frequency of HPV 16 (78\%), HPV 31 $(15.5 \%)$, and lower frequency of HPV $18(2.8 \%)$ when compared to our findings. Lorenzato et al. (2000) also found higher prevalence of HPV 31 (21.4\%) and a lower prevalence of HPV 18 (2.4\%).

Previous reports have shown that concomitant or sequential detection of more than one HPV type it is associated with different stages of cervical lesions (Silva et al. 2003, da Silva et al. 2009, Tavares et al. 2014). Our results are in agreement with the above mentioned findings: in 25 samples co-infected by HPV 16/18, 80\% (20) had high-grade of cervical lesions (neoplasia intraepithelial cervical II/III or CC).

A protector effect of the CCR2-64I polymorphism with the susceptibility of infection by HPV type 16 (OR $=0.35$ ) was observed, suggesting a possible relation of this genetic variant with protection to HPV-16 infection.

We also compared clinical features from patients with genotypic distribution of both CCR2-64I and CCR5- $\triangle 32$ polymorphisms. However, no significant difference was observed $(\mathrm{p}>0.005)$. The frequencies of $C C R 2$ and $C C R 5$ variants alleles were in agreement with a previous study in different diseases and ethnic groups (Lawhorna et al. 2013).

Thus, our data suggest that the CCR2-64I polymorphism is associated with the protective effect to development of cervical lesions as well as in the protection to HPV 16 infection.

\section{ACKNOWLEDGEMENTS}

To the patients and their families, whose collaboration and understanding have made this work possible.

\section{REFERENCES}

Ahmadabadi BN, Hassanshahi G, Khoramdelazad H, Mirzaei V, Sajadi SM, Hajghani M, Khodadadi H, Pourali R, Arababadi MK, Kennedy D 2012. Downregulation of CCR5 expression on the peripheral blood $\mathrm{CD}^{+} \mathrm{T}$-cells of South-Eastern Iranian patients with chronic hepatitis B infection. Inflammation 36: 136-140.

Al-Abdulhadi SA, Al-Rabia MW 2010. Linkage and haplotype analysis for chemokine receptors clustered on chromosome $3 \mathrm{p} 21.3$ and transmitted in family pedigrees with asthma and atopy. Ann Saudi Med 30: 115-122.

Berger EA, Murphy PM, Farber JM 1999. Chemokine receptors as HIV-1 co-receptors: roles in viral entry, tropism, and disease. Annu Rev Immunol 17: 657-700.

Bernard HU, Burk RD, Chen Z, Van Doorslaer K, Hausen H, De Villiers EM 2010. Classification of papillomaviruses (PVs) based on $189 \mathrm{PV}$ types and proposal of taxonomic amendments. Virology 401: 70-79.

Bonanni P, Bechini A, Donato R, Capei R, Sacco C, Leviand M, Boccalini S 2015. Human papilloma virus vaccination: impact and recommendations across the world. Ther Adv Vaccines 3: 3-12.

Bouvard V, Baan R, Straif K, Grosse Y, Secretan B, Ghissassi FE, Benbrahim-Tallaa L, Guha N, Freeman C, Galichet L, Cogliano V 2009. A review of human carcinogens - Part B: biological agents. Lancet Oncol 10: 321-322.

Bromley SK, Thomas SY, Luster AD 2005. Chemokine receptor CCR7 guides T-cell exit from peripheral tissues and entry into afferent lymphatics. Nat Immunol 6: 895-901.

Charo IF, Myers SJ, Herman A, Franci C, Connolly AJ, Coughlin SR 1994. Molecular cloning and functional expression of two monocyte chemoattractant protein 1 receptors reveals alternative splicing of the carboxyl-terminal tails. Proc Natl Acad Sci USA 91: 2752-2756.

Chatterjee K, Dandara C, Hoffman M, Williamson AL 2010. CCR2V64I polymorphism is associated with increased risk of cervical cancer, but not with HPV infection or pre-cancerous lesions in African women. BMC Cancer 10: 278.

Coelho A, Matos A, Catarino R, Pinto D, Pereira D, Lopes C, Medeiros R 2005. Protective role of the polymorphism CCR2-64I in the progression from squamous intraepithelial lesions to invasive cervical carcinoma. Gynecol Oncol 96: 760-764.

da Silva MF, Chagas BS, Guimarães V, Katz LM, Felix PM, Miranda PM, Lima AA, Arraes LC, Martins DB, Lima Filho JL, Stocco RC, Crovella S, Freitas AC, Beçak W 2009. HPV 31 and HPV 33 incidence in cervical samples from women in Recife, Brazil. Genet Mol Res 8: 1437-1443.

de Oliveira CM, Fregnani JH, Carvalho JP, Longatto-Filho A, Levi JE 2013. Human papillomavirus genotypes distribution in 175 invasive cervical cancer cases from Brazil. BMC Cancer 13: 357.

Evans EM, Man S, Evans AS, Borysiewicz LK 1997. Infiltration of cervical cancer tissue with human papillomavirus-specific cytotoxic T-lymphocytes. Cancer Res 57: 2943-2950.

Faul F, Erdfelder E, Lang AG, Buchner A 2007. G*Power 3: a flexible statistical power analysis program for the social, behavioral, and biomedical sciences. Behavior Research Methods 39: 175-191.

Ghaderi M, Nikitina L, Peacock CS, Hjelmstrom P, Hallmans G, Wiklund F, Lenner P, Blackwell JM, Dilnner J, Sanjeevi CB 2000. Tumor necrosis factor a-11 and DR15-DQ6 (B*0602) haplotype increase the risk for cervical intraepithelial neoplasia in human papillomavirus 16 seropositive women in northern Sweden. Cancer Epidemiol Biomarkers Prev 9: 1067-1070.

González P, Alvarez R, Batalla A, Reguero JR, Alvarez V, Astudi1lo A, Cubero GI, Cortina A, Coto E 2001. Genetic variation at the chemokine receptors CCR5/CCR2 in myocardial infarction. Genes Immun 2: 191-195.

Hall IP, Wheatley A, Christie G, McDougall C, Hubbard R, Helms PJ 1999. Association of CCR 5 delta32 with reduced risk of asthma. Lancet 354: 1264-1265.

Huang Y, Chen H, Wang J, Bunjhoo H, Xiong W, Xu Y, Zhao J 2013. Relationship between $C C R 2-V 64 I$ polymorphism and cancer risk: a meta-analysis. Gene 524: 54-58. 
Ivansson EL, Gustavsson IM, Magnusson JJ, Steiner LL, Magnusson PK, Erlich HA Gyllensten UB 2007. Variants of chemokine receptor 2 and interleukin 4 receptor, but not interleukin 10 or Fas ligand, increase risk of cervical cancer. Int J Cancer 121: 2451-2457.

Kleine-Lowinski K, Rheinwald JG, Fichorova RN, Anderson DJ, Basile J, Munger K, Daly CM, Rosl F, Rollins BJ 2003. Selective suppression of monocyte chemoattractant protein-1 expression by human papillomavirus E6 and E7 oncoproteins in human cervical epithelial and epidermal cells. Int J Cancer 107: 407-415.

Koide MD, Nishio MDA, Sato MDT, Sugiyama MDA, Miyagawa MDS 2004. Significance of macrophage chemoattractant protein-1 expression and macrophage infiltration in squamous cell carcinoma of the esophagus. Am J Gastroenterol 99: 1667-1674.

Kristiansen TB, Knudsen TB, Ohlendorff S, Eugen-Olsen J 2001. A new multiplex PCR strategy for the simultaneous determination of four genetic polymorphisms affecting HIV-1 disease progression. J Immunol Methods 252: 147-151.

Lawhorna C, Yuferova V, Randesia M, Hoa A, Morgellob S, Kreeka MJ, Levrana O 2013. Genetic diversity and linkage disequilibrium in the chemokine receptor $C C R 2-C C R 5$ region among individuals and populations. Cytokine 64: 571-576.

Lehner T 2002. The role of CCR 5 chemokine ligands and antibodies to CCR5 co-receptors in preventing HIV infection. Trends Immunol 23: 347-351.

Li N, Franceschi S, Howell-Jones R, Snijders PJ, Clifford GM 2011. Human papillomavirus type distribution in 30,848 invasive cervical cancers worldwide: variation by geographical region, histological type, and year of publication. Int J Cancer 128: 927-935.

Lorenzato F, Ho L, Terry G, Singer A, Santos LC, Lucena BR, Lubambo T 2000. The use of human papillomavirus typing in detection of cervical neoplasia in Recife (Brazil). Int J Gynecol Cancer 10: 143-150.

Miyagishi R, Niino M, Fukazawa T, Yabe I, Kikuchi S, Tashiro K 2003. C-C chemokine receptor 2 gene polymorphism in Japanese patients with multiple sclerosis. J Neuroimmunol 145: 135-138.

Mulherin SA, O’Brien TR, Ioannidis JP, Goedert JJ, Buchbinder SP, Coutinho RA, Jamieson BD, Meyer L, Michael NL, Pantaleo G, Rizzardi GP, Schuitemaker H, Sheppard HW, Theodorou ID, Vlahov D, Rosenberg PS 2003. Effects of CCR5-delta32 and CCR2-64I alleles on HIV-1 disease progression: the protection varies with duration of infection. AIDS 17: 377-387.

Nahon P, Sutton A, Rufat P, Simon C, Trinchet JC, Gattegno L, Beaugrand M, Charnaux N 2008. Chemokine system polymorphisms, survival, and hepatocellular carcinoma occurrence in patients with hepatitis $\mathrm{C}$ virus-related cirrhosis. World J Gastroenterol 14: 713-719.

Nyquist PA, Winkler CA, McKenzie LM, Yanek LR, Becker LC, Becker DM 2009. Single nucleotide polymorphisms in monocyte chemoattractant protein-1 and its receptor act synergistically to increase the risk of carotid atherosclerosis. Cerebrovasc Dis 28: 124-130.

O’Brien PM, Tsirimonaki E, Coomber DW, Millan DW, Davis JA, Campo MS 2001. Immunoglobulin genes expressed by B-lymphocytes infiltrating cervical carcinomas show evidence of antigen-driven selection. Cancer Immunol Immunother 50: 523-532.

Ohta M, Kitadai Y, Tanaka S, Yoshihara M, Yasui W, Mukaida N, Yasui W, Mukaida N, Haruma K, Chayama K 2002. Monocyte chemoattractant protein-1 expression correlates with macrophage in- filtration and tumor vascularity in human esophageal squamous cell carcinomas. Int J Cancer 102: 220-224.

Rabelo-Santos SH, Zeferino L, Villa LL, Sobrinho JP, Amaral RG, Magalhães AV 2003. Human papillomavirus prevalence among women with cervical intraepithelial neoplasia III and invasive cervical cancer from Goiânia, Brazil. Mem Inst Oswaldo Cruz 98: 181-184.

Rossi D, Zlotnik A 2000. The biology of chemokines and their receptors. Annu Rev Immunol 18: 217-242.

Silva AMTC, Amaral MVT, Cruz AD 2003. O papel do papiloma vírus humano no câncer. Biotecnol Cienc Desenvol 29: 48-54.

Smith MW, Dean M, Carrington M, Winkler C, Huttley GA, Lomb DA, Goedert JJ, O'Brien TR, Jacobson LP, Kaslow R, Buchbinder S, Vittinghoff E, Vlahov D, Hoots K, Hilgartner MW, O’Brien SJ 1997. Contrasting genetic influence of CCR2 and CCR5 variants on HIV1 infection and disease progression. Hemophilia Growth and Development Study (HGDS), Multicenter AIDS Cohort Study (MACS), Multicenter Hemophilia Cohort Study (MHCS), San Francisco City Cohort (SFCC) ALIVE Study. Science 277: 959-965.

Solomon D, Davey D, Kurman R, Moriarty A, O'Connor D, Prey M, Raab S, Sherman M, Wilbur D, Wright Jr T, Young N, Forum Group Members, Bethesda 2001. Workshop 2002. JAMA 287: 2114-2119.

Spinillo A, Tenti P, Zappatore R, De Seta F, Silini E, Guaschino S 1993. Langerhans' cell counts and cervical intraepithelial neoplasia in women with human immunodeficiency virus infection. Gynecol Oncol 48: 210-213.

Tavares MCM, de Lima Jr SF, Coelho AV, Marques TRN, Araújo DHT, Heráclio SA, Amorim MMR, de Souza PRE, Crovella S 2015. Tumor necrosis factor (TNF) alpha and interleukin (IL) 18 genes polymorphisms are correlated with susceptibility to HPV infection in patients with and without cervical intraepithelial lesion. Ann Hum Biol 16: 1-8.

Tavares MCM, Macêdo JL, de Lima Jr SF, Heráclio SA, Amorim MMR, Maia MMD, Souza PRE 2014. Chlamydia trachomatis infection and human papillomavirus in women with cervical neoplasia in Pernambuco-Brazil. Mol Biol Rep 41: 1-10.

Tay SK, Jenkins D, Maddox P, Hogg N, Singer A 1987. Tissue macrophage response in human papillomavirus infection and cervical intraepithelial neoplasia. Br J Obstet Gynaecol 94: 1094-1097.

Wallin KL, Wiklund F, Angstrom T, Bergman F, Stendahl U, Wadell G, Hallmans G, Dillner J 1999. Type-specific persistence of human papillomavirus DNA before the development of invasive cervical cancer. $N$ Engl J Med 341: 1633-1638.

Zafiropoulos A, Crikas N, Passam AM, Spandidos DA 2004. Significant involvement of CCR2-64I and CXCL12-3a in the development of sporadic breast cancer. J Med Genet 41: e59.

Zapico I, Coto E, Rodriguez A, Alvarez C, Torre JC, Alvarez V 2000. CCR5 (chemokine receptor-5) DNA-polymorphism influences the severity of rheumatoid arthritis. Genes Immun 1: 288-289.

Zhang T, Koide N, Wada Y, Tsukioka K, Takayama K, Kono T, Kitahara H, Amano J 2003. Significance of monocyte chemotactic protein-1 and thymidine phosphorylase in angiogenesis of human cardiac myxoma. Circ J 67: 54-60.

Zheng B, Wiklund F, Gharizadeh B, Sadat M, Gambelunghe G, Hallmans G, Dillner J, Wallin K, Ghaderi M 2006. Genetic polymorphism of chemokine receptors CCR2 and CCR5 in Swedish cervical cancer patients. Anticancer Res 26: 3669-3674. 